\title{
Strategic Government Spending in South Korea and Taiwan: Lessons for Emergent Democracies*
}

\author{
O. Fiona Yap, University of Kansas
}

Objectives. How is government spending used strategically in South Korea and Taiwan? As nations generally considered to have weathered democratization, government allocations in South Korea and Taiwan are instructive on how spending may be used strategically without undermining democratization. Methods. The similar sociocultural, historical, political, and economic experiences of the two nations underlie a most-similar-systems approach to study how their differences influence diversity in strategic spending and, correspondingly, political outcomes such as size of the government party in the legislature. This article evaluates defense and civilian expenditures for South Korea and Taiwan from 1975 to 2006. Results. Three results are interesting. First, different elections-legislative elections in South Korea, presidential elections in Taiwan-lead to increases in spending. Second, in both nations, defense spending increases in election years but not social spending; however, defense spending benefits the government-party in the legislature in South Korea but not in Taiwan. Third, when the strategic uses of spending are accounted for, democratization does not directly affect allocations. Conclusions. These results explicate that government spending is a viable resource for party building in new democracies; however, the results also underscore that governing parties in new democracies benefit from spending only insofar as it is used to build the nation's or party's strengths — not undermine the opposition-under competitive elections.

How is government spending strategically used in the emergent Asian democracies of South Korea and Taiwan? Strategic spending refers to spending targeted at broadening electoral support. Government spending is among the most important pieces of legislation passed in any year and provides insights into the scope and vigor of political development. In emergent democracies, government spending is particularly relevant: it is a viable alternative for use in party development or building government support, given the constraints on political patronage and limits on resource

\footnotetext{
*Direct correspondence to O. Fiona Yap, Department of Political Science, University of Kansas, Lawrence KS 66044〈fyap@ku.edu〉. I thank Robert Lineberry, Dorothy Daley, Dennis Duermeier, the anonymous reviewers for the journal, and participants at the "Parties, Elections, and Movements in East Asia" panel of the Western Political Science Association, 2009, for comments and suggestions. The responsibility for all mistakes remains with me. Data and coding information for replication is available upon request.
} 
uses as a result of democratization (Cheng and Haggard, 2001; Kwon, 2005). Generally, studies of Latin American and postcommunist Europe show that government spending is influenced by three strategic considerations: elections, parties in the legislature, and democratization. Further, increases are targeted at civilian allocations rather than defense spending. Thus far, extensions to Asian emergent democracies have been limited. This is unfortunate: South Korea and Taiwan are valuable for examination, given that these Asian economies are considered successes in democratization even as concerns rise over democratic progress in their non-Asian counterparts (Cheng and Haggard, 2001; Carothers, 2007; Berman, 2007; Schedler, 2002). Thus, a study of the strategic uses of government spending for the two nations broadens scholarship and is instructive on how allocations may be used strategically without undermining democratization. Further, the systematic investigation of Taiwan and South Korea-two nations that share similarities in sociocultural characteristics and legacies of colonization, strong government, and interstate conflict-provide a "most-similar-systems" approach that emphasizes the varied considerations that influence strategic government spending and the divergent effects on outcomes such as size of the government party in the legislature. ${ }^{1}$

This article systematically examines the strategic use of government spending in South Korea and Taiwan, specifically, defense and social welfare allocations. We also consider the impact of government spending on support. Thus, our analyses round out the findings of strategic uses of spending by analyzing how government allocations affect the size of the executive party in the legislature. The data run from 1975 to $2006 .^{2}$ Longitudinal analyses for individual countries, considered the best research design for causal tests, are used (Chan, 1995; Coppedge, 2002; Pereira, Power, and Rennó, 2005). Defense spending refers to spending on defense and the military and includes equipment, facilities, welfare, education and training of military personnel, and expenses for maintaining reserve forces and foreign military aides such as the U.S. Forces. ${ }^{3}$ Interestingly, war-time expenses and war preparation, including purchases of major weaponry, are not represented in the normal budget but captured as special, extraordinary, or emergency budget requests. ${ }^{4}$ In both nations, then, defense spending cap-

\footnotetext{
${ }^{1}$ We thank an anonymous reviewer for suggesting that we make this point explicit. Most similar-systems designs are small $N$ studies that rely on using similarities across countries to offset the effects of those commonalities as causes and, instead, allow researchers to focus on the variants between the systems as explanations.

${ }^{2}$ Data availability for the democratization variable, obtained from Freedom House, determined the start date/year of 1975 .

${ }^{3}$ See, for instance, Defense White Paper 1997-2006 (Ministry of National Defense, South Korea), and "Special Defense Budget" (Keesings Record of World Events, June 2004).

${ }^{4}$ We note that this classification of war-time preparations and war expenses is not unique to Taiwan and South Korea. Thus, for instance, in the United States, the estimated $\$ 420$ billion to fund military operations in Iraq and Afghanistan since September 11, 2001, are through supplemental appropriations and not the regular budgetary process (New York
} 
tures only recurring defense and military expenses. Social spending comprises spending on social welfare payments, health, pensions, economic development, and education. The term social spending is used interchangeably with civilian spending.

Three findings from this article are relevant to the literature. First, elections predict spending increases. However, the effects of elections are nuanced: for South Korea, legislative election years see changes; in Taiwan, it is presidential election years. These nuances reflect strategic responses to the electoral settings of the respective nations. Specifically, in South Korea, where the presidential tenure is limited to a single five-year term, it is strategic to focus electoral spending on legislative elections to avoid a lameduck presidential term. In Taiwan, where the presidential tenure is limited to two terms but legislators were elected (until 2008) from multimember districts with a single nontransferable vote (SNTV), the focus on presidential elections may be easier and preferable. This finding points to the need to contextualize spending in domestic politics to frame expectations.

Second, democratization has no direct impact on defense or civilian spending. This finding is corroborated in different tests. Why does democratization not affect spending decisions in South Korea or Taiwan? In part, the effect of democratization is indirect, that is, it is attenuated by the inclusion of variables such as size of the government party, legislative fragmentation, and separate legislative and presidential elections. Thus, the results highlight the relevance of democratization for changing spending priorities due its effect on increasing competitiveness rather than as a direct effect. Partly, the results also show that the difference between pre- and postdemocratization spending patterns in South Korea and Taiwan is a matter of degree rather than of fundamentals. This is consistent with recent studies: the effects of democratization on government spending are more nuanced than originally conceived, especially when strategic considerations are incorporated into the analyses (Kwon, 2005; Stasavage, 2005; Samuels and Abrucio, 2000; Kaufman and Segura-Ubiergo, 2001). The results, then, corroborate a growing literature that points out strategic priorities in spending even in less-democratic countries or predemocratization periods.

Third, in both nations, election years lead to growth in defense spending but not in civilian outlays. Although these results seem contrary to the literature, they are consistent with competitive platforms in both nations and, again, emphasize the relevance of the domestic context for framing predictions. As detailed in the section on politics and spending priorities,

Times, June 16, 2006). See Office of Management and Budget, The Budget of the US, available at $\langle$ http://www.gpoaccess.gov/usbudget/ $\rangle$, accessed September 18, 2008. For Taiwan, see Central News Agency, "Defense Ministry to Take Another Stab at Publicity for US Arms Deal," March 3, 2005. In South Korea, war preparation and expenses fall under the combined Korea-U.S. Forces and do not appear in the regular budget. See the Ministry of National Planning and Budget, National Budget (2001, 2002, 2003, 2004, 2005, 2006), available at $\langle$ http://www.mpb.go.kr $\rangle$, accessed August 23, 2008. 
South Korea developed a defense industry in the 1970s and is currently a competitive exporter of defense systems (Korea Annual, 1978; Armstrong, 2001). Defense spending in South Korea, then, is consistent with distributive benefits. In Taiwan, a strong defense posture has led to hostile stances from China; this, in turn, stirs and galvanizes support for the oppositionleader-turned-president Chen Shui Bian and his platform. Thus, defense spending is also strategic. Importantly, the growth in defense spending increases support for the governing party in South Korea but decreases that support in Taiwan. This finding rounds out the strategic use of government allocations to show their effects on support for the government. The result is probably not surprising for South Korea, given that the defense spending may also represent constituency or pork-barrel spending. It is illuminating for Taiwan: specifically, it shows that voters do not reward the government for building its party through divisive politics.

In conjunction, these results highlight the strategic uses of government spending for new democracies. Specifically, they show what, how, and why spending broadens electoral support in emergent democracies and underscore the need to contextualize allocations in domestic politics to secure and broaden political support. In the following, we detail how elections, parties in the legislature, and democratization influence spending in South Korea and Taiwan. Then, we describe the variables and tests, discuss the results, and conclude with implications.

\section{Theory and Politics of Spending in South Korea and Taiwan}

The literature on spending in emergent democracies shows that government expenditures are used strategically to broaden electoral support or increase legislative backing or some combination of both as a result of democratization. Thus, some studies report that spending increases during election years due to government manipulation to enhance reelection prospects (Kwon, 2005; Treisman and Gimpelson, 2001). Others show that governments shift priorities toward responding to constituency demands to broaden social support and away from cultivating ties with the military for political survival (Orenstein, 2008; Lebovic, 2001; Brown and Hunter, 1999). Still others note that spending may increase because the newly empowered parties in the legislature are unwilling or unable to make short-term choices to curb government spending (Reich, 1999; Cheng and Haggard, 2001).

Do these three strategic considerations affect spending decisions in South Korea and Taiwan? We suspect that the effects of these factors are contextualized by domestic concerns. Thus, for instance, while elections are important, resource competition between the executive and the legislature may render one election to be more important than another. Similarly, while parties in the legislature affect spending, the fact that parties and citizenry in the two nations are not strictly left-right aligned and social spending not 
ideologically based suggests that their effects are modest (Haggard and Kaufman, 2008:259-60). Likewise, while democratization is expected to change government priorities, studies also show that authoritarian governments may use spending to motivate or buttress support from their constituencies. In such cases, spending patterns may not be structurally distinct between pre- and postdemocratization periods. Nevertheless, with competitive elections as a result of democratization, the success of strategic government spending — particularly for building electoral support or increasing legislative backing or some combination of both-is revealed. In the following, we detail how the three factors affect spending in the two nations.

\section{Contextualizing Strategic Government Spending in South Korea}

How do elections, parties in the legislature, and democratization affect defense and civilian spending in South Korea? We begin with an assessment of electoral effects. Executive and legislative elections have been held since 1948. They are widely contested in South Korea, even though they were not always free from fraud. In 1972, President Park Chung-hee adopted the Yushin Constitution (Revitalizing Reforms) that concentrated power in the executive and made it an indirectly elected office. This affected the integrity of electoral contestation; nevertheless, elections to the executive and legislature continued to be held (Korea Annual, 1970-1980). Park was assassinated on October 26, 1979; General Chun Doo-hwan, who took over as acting president about 10 months following the assassination, maintained the indirect election of the executive in the Fifth Republic established in 1980 (Yap, 2005). Ensuing political activism led to popular demands for constitutional and electoral reforms; in 1987, the government yielded. The Sixth Republic, promulgated on October 29, 1987, set up a semi-presidential system with a directly elected president and a cabinet responsible to the legislature (Korea Annual, 1988).

Elections, then, comprise competitive elements even in the predemocratization period. Which elections affect spending? In South Korea, it is strategic to focus on legislative election spending, for one reason: institutionally, the president's tenure is limited to a single five-year term, that is, without the possibility of reelection. This eliminates resource competition between the two branches of the government, in which the executive, with powers granted by the constitution, would undoubtedly prevail. Specifically, the constitution circumscribes legislators' role: Articles 42 and 89 stipulate that the executive drafts and presents the budget for legislative approval, while Article 57 stipulates that legislators may not increase or create any new expenditure items in the budget bill (Constitution of the Republic of Korea). Instead, the single-term executive, who is potentially a lame-duck executive unless she or he is able to rally support from the legislature, has the incentive to distribute allocations and fund pork-barrel projects to reward support or 
win supporters for the executive's agenda during his or her one term in office. As a result, it is strategic for South Korean presidents to use the carrot of increasing spending during legislative elections to enhance electoral success in the legislature.

What are the effects of parties in the legislature? Government spending is generally used strategically in two ways: (1) to increase the size of the government party in the legislature and (2) to reward legislative support. How do these apply to South Korea? In South Korea, the legislative role is constitutionally limited, so that much of the spending for or by parties in the legislature depends on the relations with the executive. Prior to democratization, the executive enjoyed the support of a majority government-party in the legislature. By this consideration, spending likely increases to reward legislative support. Following democratization, the ruling government-parties have not maintained a legislative majority (Yap, 2005). Nevertheless, there is a consistent effort on the part of the executive to elicit cooperation among legislative parties. Thus, for instance, in 1990, a political merger between the ruling party and opposition parties led to a new, majority Democratic Liberal Party (DLP) in the legislature (Oh, 1999). However, in the first legislative elections in 1992 following the merger, the electorate reduced the DLP's legislative margin to a plurality (Yap, 2005). Indeed, except for a brief period between 2004 and 2005, the party of the president has consistently failed to secure an outright majority in the legislature. By this account, since democratization, the need to increase the size of the government party in the legislature or reward legislative support from other parties leads to increases in spending.

Which area of spending-defense or civilian allocations - is likely to increase as a result of the effects of elections, parties in the legislature, and democratization? Prior to democratization, the South Korean government is disposed to favor the military with spending. Postdemocratization, defense spending remains a priority because of the manufacturing competitiveness of its defense industry. In 2007, South Korea defense exports totaled US\$850 million; exports for 2008 are expected to exceed US $\$ 1$ billion (Yonhap News Agency, Aug 4, 2008). The economic importance of the defense industry is probably underscored by the Defense Reform Policy 2020, which establishes several prerogatives in modernizing and reforming the military by year 2020 (Ministry of National Defense, 2006). Among the goals articulated is the achievement a self-reliant defense posture through the development of the military complex; it also sets up a growing defense budget to accomplish the reforms. Thus, in terms of both economic possibilities and pork-barrel spending, defense spending is likely to remain a priority.

What about civilian spending? Civilian expenditures are not ideologically motivated: parties and the citizenry in South Korea are not aligned in terms of civilian spending. Indeed, Haggard and Kaufman contend that the pattern of civilian spending in South Korea is cyclical and correlated with the wealth of the nation (2008:45-47). Our analysis of civilian spending over 
time supports this interpretation: civilian allocations averaged 43 percent of total government spending in the 1970 s, constrained probably by the oil crisis. They rose to almost 50 percent in the 1980s but fell by 10 percent in the 1990s (Asian Development Bank, 1990-2008); this is consistent with economic circumstances related to the financial crisis that severely hit South Korea. Since 2000, civilian spending has gone back to almost 50 percent of total government spending, facilitated by the country's economic recovery. By this account, civilian spending is likely to remain cyclical and tied to economic wealth rather than to elections or parties.

To summarize, in terms of defense and civilian spending, we expect South Korea to show electoral spending to broaden support. However, the area targeted is likely to be defense rather than civilian allocations. Thus, the results are likely to depart in the specifics from the literature.

\section{Contextualizing Defense and Civilian Spending in Taiwan}

How do elections, parties in the legislature, and democratization affect defense and civilian spending in Taiwan? Elections matter in Taiwan: although the "Temporary Provisions" in 1948 placed Taiwan under martial law and suspended national elections for all elective offices, local elections were held for county magistrates, city mayors, and council representatives. Beginning in 1969, supplementary elections were carried out for seats to the national offices; by 1971, limited national elections were held for the legislature, the Control Yuan, and the National Assembly (Tien, 1996). In September 1986, in anticipation of the lifting of martial law, the Democratic Progressive Party (DPP) formally constituted as an opposition party to contest elections (Republic of China Yearbook, 1981-1998). Following the termination of the Temporary Provisions in 1991, legislative elections were held in December 1992, and in 1996, Taiwan held its first direct election of the president and vice president (Taiwan Communique, 1993; Republic of China Yearbook, 1991).

As in South Korea, elections in Taiwan comprise competitive elements even in predemocratization periods. Which elections affect spending and how? The constitution in Taiwan gives the executive priority and restrains the effect of the legislature: Article 70 specifies that legislators may not increase or create expenditures in the budgetary bill presented by the executive. Further, the executive retains the ability to propose additional spending (Constitution of the Republic of China). In Taiwan, there is the potential for resource competition between the president's and the legislature's agenda: the electoral system limits the presidency to two terms, while elections to the legislature are via SNTV, multimember districts. Thus, a second-term president is more willing to distribute resources in favor of the legislature than a first-term one. Nevertheless, targeting spending in favor of 
particular legislators is difficult in SNTV, multimember districts. Thus, presidential elections are more likely to see increases in spending.

What is the effect of parties in the legislature on spending? Spending by parties in the legislature depends on the relations with the executive, given that the legislative role is constitutionally circumscribed. Under both the KMT and the DPP governments, executive-legislature relations have been poor. For the KMT, democratization saw a rise in in-party fighting and party splits that fractured relations in the party and between the executive and legislature. Under the DPP government, which ran the presidency since 2000 and also had a plurality in the legislature between 2000 and 2004, legislative gridlock is a recurrent theme (Taipei Times, December 31, 2002, October 22, 2003). By the 2004 legislative elections in December, the panblue coalition, comprising the KMT and its former allies, secured a majority of 114 seats in the 225-seat legislature (BBC Worldwide Monitoring, March 22, 2004; Yap, 2005). Given the executive-legislature tensions since democratization, the executives are not likely to use spending to help legislators.

Which area of spending - defense or civilian allocations - is likely to increase as a result of the effects of elections, parties in the legislature, and democratization? Taiwan's defense spending bears many similarities to its counterpart in South Korea. Thus, prior to democratization, the government favored the military for its support with defense spending. Notably, defense spending has remained a priority under the opposition-turned-governingparty DPP administration. Thus, in the 2002 budget proposal, defense remained the largest allocation; in 2004, the government proposed a special budget of US $\$ 20$ billion for military purchases (which stalled in the legislature until 2007); and in 2007, president Chen Shui-bian railed against the opposition's efforts to cut defense spending as surrendering Taiwan to China (Taipei Times, July 27, 2002; Keesings Record of World Events, June 2004; Central News Agency, October 21, 2007). Why has defense spending remained a priority? Defense is tied to an important rallying issue for the DPP and one that potentially divides its opponents: Taiwan's identity in relation to China. On this issue, China often played the unwitting accomplice, flexing its military muscle more than once to steer election results. ${ }^{5}$ A more politically sophisticated China has recognized that these reactions are ultimately counterproductive and has refrained from such engagements. Notwithstanding, defense spending is tied to a politically and emotionally charged issue for Taiwan and China; its priority, then, keeps the issue in the political forefront.

What about social spending? Civilian spending patterns have not changed with government changes. Partly, this follows because civilian spending is tied to the government's largesse: in better economic times, this facilitates the expansion of benefits and entitlements (Haggard and Kaufman, 2008). Partly,

\footnotetext{
${ }^{5}$ Thus, in 1996, China conducted missile tests in the Taiwan Straits to steer election outcomes against then-president Lee Teng-hui. In 2000, China issued a policy paper explicitly threatening the use of military force if Taiwan declares independence (BBC Worldwide Monitoring, March 22, 2004).
} 
this also follows from the fact that social spending in Taiwan is not party specific (Haggard and Kaufman, 2008; Yap, 2005). Thus, for instance, in the 1991-1996 national development plan, the then-KMT government targeted increases in civilian spending as part of the platform to upgrade "all aspects of life" (Yap, 2005). Conversely, the opposition-turned-governing-party, the DPP administration, declared social spending a "stumbling block" to the government's priority of economic development (Taipei Times, October 28, 2000). By these considerations, civilian spending is likely to remain tied to economic cycles rather than to parties in government. In sum, elections and executive-legislature relations reinforce defense spending in Taiwan.

The overview of politics and institutions in South Korea and Taiwan show that government spending may be strategically used for building support or party development, especially during elections. Two characteristics in both nations - the president's authority and the electoral settings-contribute to increase defense spending and not civilian allocations during election years. Additionally, in South Korea, defense allocations are economically and politically savvy because of the economic expansion of defense as an industry. Thus, it is useful either in terms of economic development or as pork-barrel spending. In Taiwan, increases in defense spending seem contraindicated in a liberal-populist platform of the opposition-turned-governing-party (the Democratic Progressive Party (DPP)). Nevertheless, defense has been sheltered from cuts even under the DPP because a strong defense posture provokes China and, in turn, stirs and galvanizes support for the DPP. How does democratization affect spending? The discussion on elections and parties in the legislature shows that competition and constituency support are not unique to the postdemocratization periods in either nation. This suggests that democratization is not likely to provide fundamental shifts in spending patterns. The next section describes the tests.

\section{Hypotheses and Variables}

We heed the call to use time-series analyses for robust findings. Accordingly, we evaluate government allocations in South Korea and Taiwan using the following hypotheses.

$\mathrm{H}_{1}$ : Political considerations, specifically elections, affect defense or civilian allocations. In South Korea, controlling for economic conditions, governingparty strength, and legislative fragmentation, legislative elections lead to growth in defense spending, notwithstanding democratization. In Taiwan, controlling for economic conditions, governing-party strength, and legislative fragmentation, presidential elections lead to growth in defense spending, notwithstanding democratization.

$\mathrm{H}_{2}$ : The size of the government-party in the legislature is affected by the politics of defense or civilian allocations. In South Korea, controlling for democ- 
ratization and economic conditions, growth in defense spending increases the government-party in the legislature. In Taiwan, controlling for democratization and economic conditions, rise in defense spending fails to increase the government-party in the legislature.

The variables are described next. The data are obtained from individual country sources, such as the respective election commissions and statistical departments, and also from regional and international sources such as the Asian Development Bank and World Bank.

\section{Dependent Variables-Defense and Civilian Allocations}

We are interested in patterns of government spending as related to defense and civilian spending. Defense spending refers to spending on defense and the military. War-time expenses and war preparation, including purchases of major weaponry, are not represented in the normal budget. Civilian spending or social spending comprises spending on social welfare, economic development, education, and health. Real growth in defense and civilian spending are used for three reasons. First, they document absolute spending increases, rather than relative sizes, so that spending priorities are clear. Second, economic controls such as inflation may be excluded from the analyses if found to have no effect if real spending is used, to preserve degrees of freedom. Third, raw economic data, such as actual spending, invariably suffer from unit root problems. Such variables comprise a deterministic trend plus a stochastic trend, so that the variable shows an "increasing variance around a linear trend." ${ }^{, 6}$ When variables with unit roots are used in regressions, the results are biased toward statistical significance, although none may exist. Consequently, the literature consistently uses percentage growth data, which eliminate the unit root problems through differencing, to study spending.

\section{Independent Variables of Interest_Elections and Democratization}

We investigate the effects of elections and democratization. We use election variables to capture legislative and executive races separately. Elections are coded as 1 during the respective election years and 0 otherwise. ${ }^{7}$ The democracy variable is derived from the Freedom House's Political Freedom Index (Freedom House, 1972-2009). Specifically, the scales measuring civil and political freedom are added and inverted so that the scale ranges from 2

\footnotetext{
${ }^{6}$ See Greene (2002:635).

${ }^{7}$ Given the emergent democracies and the relative lack of political resources (for new parties and compared to predemocratization periods), and restrictions on resource use in elections, we focus on electoral spending effects for the actual electioneering year.
} 
(least democratic) to 14 (most democratic) (Lebovic, 2001). Democratization is measured on a scale to capture the incremental process of democratization (Feng et al., 2000; Bollen and Jackman, 1989). We note, nonetheless, that the results are not substantively different using a continuous or a dichotomous measure of democracy, that is, the results for the other variables are stable, while the variables measuring democratization remain statistically insignificant. ${ }^{8}$

\section{Independent Control Variables-Economic Conditions, Government- Party, Parties in the Legislature, and Total Spending}

Economic conditions may influence government spending. We evaluated several control variables for use, including: real growth in the gross domestic product (GDP), unemployment, inflation, interest payments, trade, foreign exchange, and openness of the economy. Only real growth in GDP is statistically related to the allocations. In the interest of parsimony and to preserve degrees of freedom, we adopt the real growth in GDP to control for the economy. Two other controls are the size of the government-party in the legislature and total government spending. The size of the government-party in the legislature, calculated as the proportion of seats that the government's party holds in the legislature and obtained from the Database of Political Institutions, is added to control for possible effects that government-party may have on allocation (Beck et al., 2001). Parties in the legislature is captured through legislative fragmentation, which is calculated from the probability that two deputies in the legislature are from different parties and is obtained from the Database of Political Institutions (Beck et al., 2001). The variable controls for spending increases due to the rise in parties in the legislature that are unwilling or unable to make short-term choices to curb government spending (Reich, 1999; Cheng and Haggard, 2001). Total government spending, which includes defense, civilian, and administrative allocations and interest payments, is also added as a control. It takes into account that defense and civilian spending allocations may not necessarily change at each other's expense. The real growth in total government spending is used; this eliminates potential correlation with economic variables.

To summarize, the two dependent variables are real growth in defense and civilian spending. The independent variables of interest are presidential and

\footnotetext{
${ }^{8}$ Thus, the results from a dichotomous operationalization of democratization for South Korea, using 1987 as the turning point, report parameter estimates of $-2.36(p=0.46)$ for defense and $5.28(p=0.59)$ for civilian spending. For Taiwan, there are more possibilities for interpreting when regime change occurred: using 1987 as one turning point, the results for defense and civilian spending are $-7.17(0.27)$ and $-01.72(0.61)$, respectively; using 1992 , the results are $-1.74(0.76)$ and -0.64 (0.83), respectively; and using 1996, the results are $1.35(0.81)$ and $2.09(0.47)$, respectively. The results from using the continuous variable (which is derived from the Freedom House measures) are the same as those reported in the tables. See Kwon (2005).
} 
legislative elections, democratization, and legislative fragmentation (parties in the legislature). Controls used are: real growth in the GDP, proportion of the government's party in the legislature, and real growth in total government spending. The next section describes the results.

\section{Findings}

We evaluate the data for time-series problems such as nonstationarity and serial correlation. Two variables reveal potential unit root problems: the size of the government-party in the legislature and legislative fragmentation. The variables are differenced and used. ${ }^{9}$ There are no problems from serial correlation. ${ }^{10} \mathrm{We}$ also tested for structural breaks in the spending data for preand postdemocratization periods. ${ }^{11}$ The results show no problems with structural breaks; this means that spending patterns are not fundamentally different for pre- and postdemocratization periods. The following equations are used in the analyses.

$$
\begin{aligned}
& \text { Real growth in defense (civilian) allocation } \mathrm{t}_{\mathrm{t}} \\
& =\alpha_{1}+\beta_{1} \text { democratization }_{\mathrm{t}}+\beta_{2} \text { presidential election }_{\mathrm{t}} \\
& +\beta_{3} \text { legislative election }{ }_{\mathrm{t}}+\beta_{4} \text { change in executive }- \text { party strength } \\
& \text { in the legislature } \mathrm{t}_{\mathrm{t}-1}+\beta_{5} \text { change in legislative party fragmentation } \mathrm{n}_{\mathrm{t}-1} \\
& +\beta_{6} \text { real growth in GDP growth }{ }_{\mathrm{t}}+\beta_{7} \text { real growth in total } \\
& \text { government spending }{ }_{\mathrm{t}}+\varepsilon_{1 \mathrm{t}}
\end{aligned}
$$

Change in the proportion of executive party control of the legislature $\mathrm{t}_{\mathrm{t}}$

$$
\begin{aligned}
& =\alpha_{1}+\beta_{1} \text { democratization }_{\mathrm{t}}+\beta_{2} \text { real growth in social spending } \mathrm{t}_{\mathrm{t}-1} \\
& +\beta_{3} \text { real growth in defense spending } \\
& +\beta_{4} \text { real growth in GDP growth } \\
& \mathrm{t}-\varepsilon_{1 \mathrm{t}}
\end{aligned}
$$

${ }^{9}$ The results from the augmented Dickey-Fuller test for nonstationarity are reported in Table 4. The augmented Dickey-Fuller test evaluates if a variable follows a unit root process. The null hypothesis is that the variable contains a unit root. Differencing variables with unit root problems generally leads to a stationary series.

${ }^{10}$ The results of the autocorrelation tests are reported in the individual tables for clarity.

${ }^{11}$ The results are based on the Chow test, a test of whether the coefficients estimated over one group of data are equal to the coefficients estimated over another. See the discussion on Chow tests by William Gould, StataCorp, available at $\langle$ http://www.stata.com/support/faqs/ stat/chow3.html $\rangle$. The null hypothesis is structural stability. For South Korea, the $F$ statistic from the Chow test for periods of pre- and postdemocratization for defense spending is 1.76 $(p=0.16)$ and for civilian spending is $0.54(p=0.79)$. For Taiwan, the $F$ statistic from the Chow test for periods of pre- and postdemocratization for defense spending is 1.21 $(p=0.35)$ and $0.29(p=0.95)$. The results, then, show that the null of structural stability cannot be rejected. 
Thus, Equation (1) evaluates how elections and legislative fragmentation affect spending decisions, controlling for democratization and the economy, while Equation (2) rounds out the analysis to show how the size of the government-party in the legislature is affected by spending decisions from the previous year. An important note: given South Korea's and Taiwan's longstanding discords with their neighbors of North Korea and China, respectively, we evaluate for the effects of hostilities on defense spending by including interstate hostilities (Ghosn et al., 2004). It is not statistically significant but does inflate the standard errors of the model for both nations. Because it shortens the data series, it is omitted in the final analysis.

What do the results show? In general, the results are as expected. Specifically, in South Korea, the results show that legislative elections lead to increases in defense spending, while in Taiwan, executive election years lead defense allocations to increase. Importantly, in both nations, the election variables are statistically significant even with controls for the economy, size of the government-party, and legislative fragmentation. As expected, democratization is not statistically significant; further, the lack of effect is consistent for the postdemocratization data and for the longer series that include predemocratization periods. Table 1 reports the Huber-White robust regression estimates for defense spending for South Korea and Taiwan. Columns 1 and 2 report the results for South Korea for the postdemocratization period and the longer series, respectively; Columns 3 and 4 show the comparable results for Taiwan.

The findings for social spending from Huber-White robust regression estimation are tabulated in Table 2. They show that elections do not predict social spending; in fact, the only consistent variable predicting social spending is growth in total government spending. They also show that democratization does not exert an effect independent of the variables used in the analyses; this is also consistent across the postdemocratization data and the longer series. The results for postdemocratization and the longer series for South Korea are reported in Columns 1 and 2, respectively; Columns 3 and 4 show the equivalent for Taiwan.

To round out the analyses, we evaluate how defense and civilian allocations affect the size of the government's party in the legislature. If our conjecture about defense spending as an economic and pork-barrel priority in South Korea is correct, then the results will show that growth in defense spending increases the size of the government's party in the legislature. We offer no predictions for Taiwan. We also offer no predictions on the effect of civilian allocations, given that we do not expect social welfare allocations to be ideological or electorally related. Table 3 tabulates the results based on Huber-White robust regression analyses. As before, Columns 1 and 2 report the results for South Korea; Columns 3 and 4 for Taiwan.

The results show that the individual variables do not explain the size of the government's party in the legislature in either nation, although the social spending shows a negative and statistically significant effect for the larger 


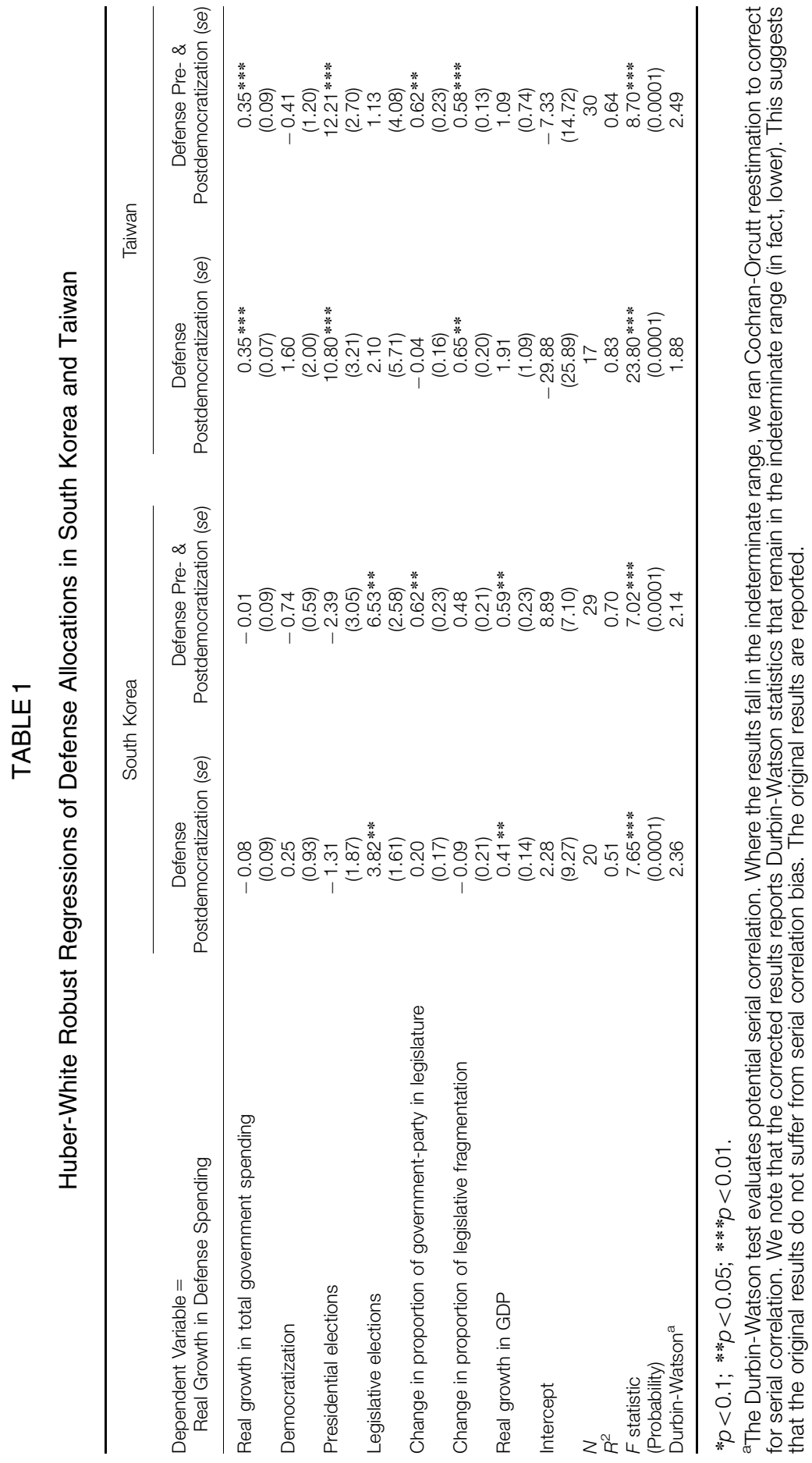




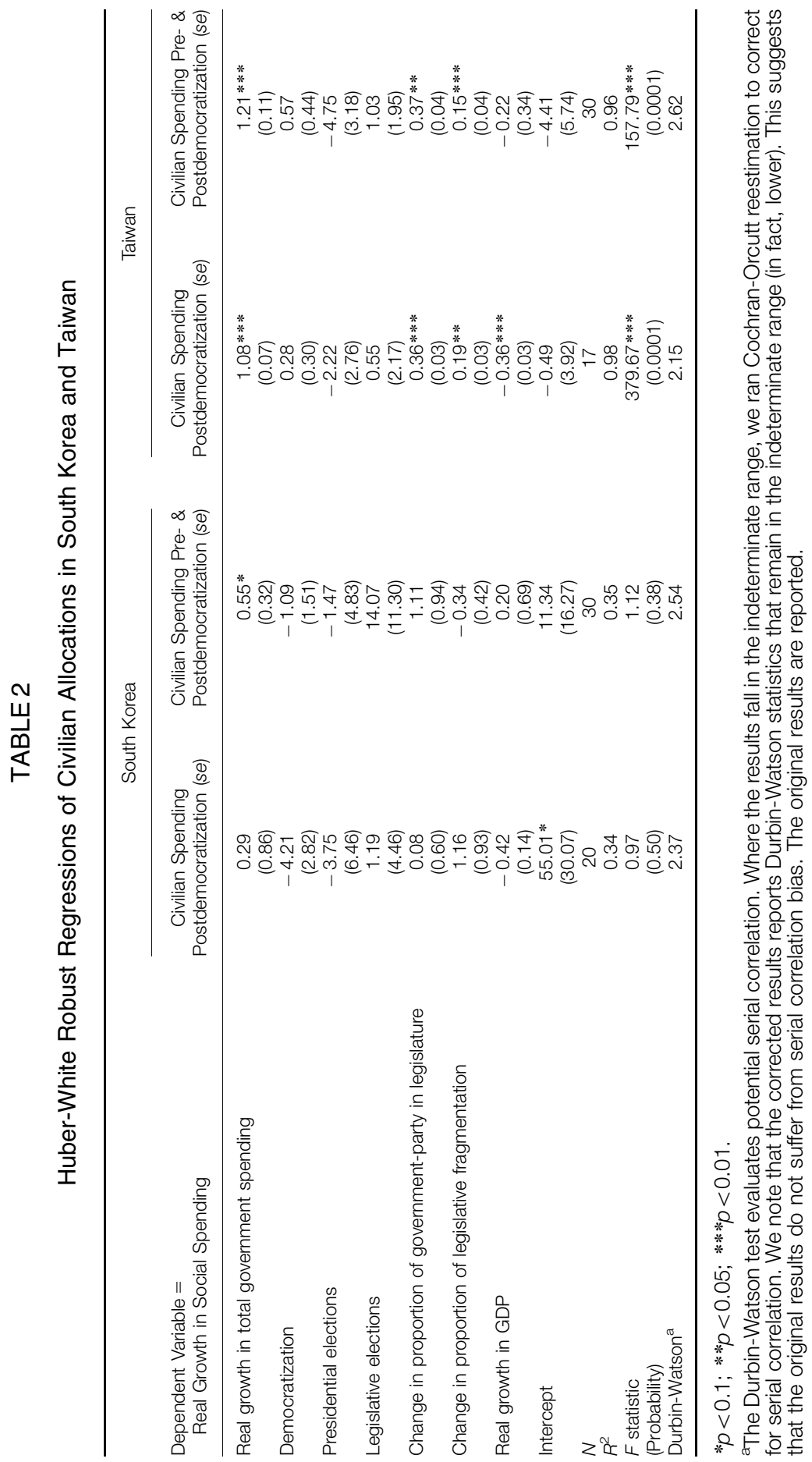




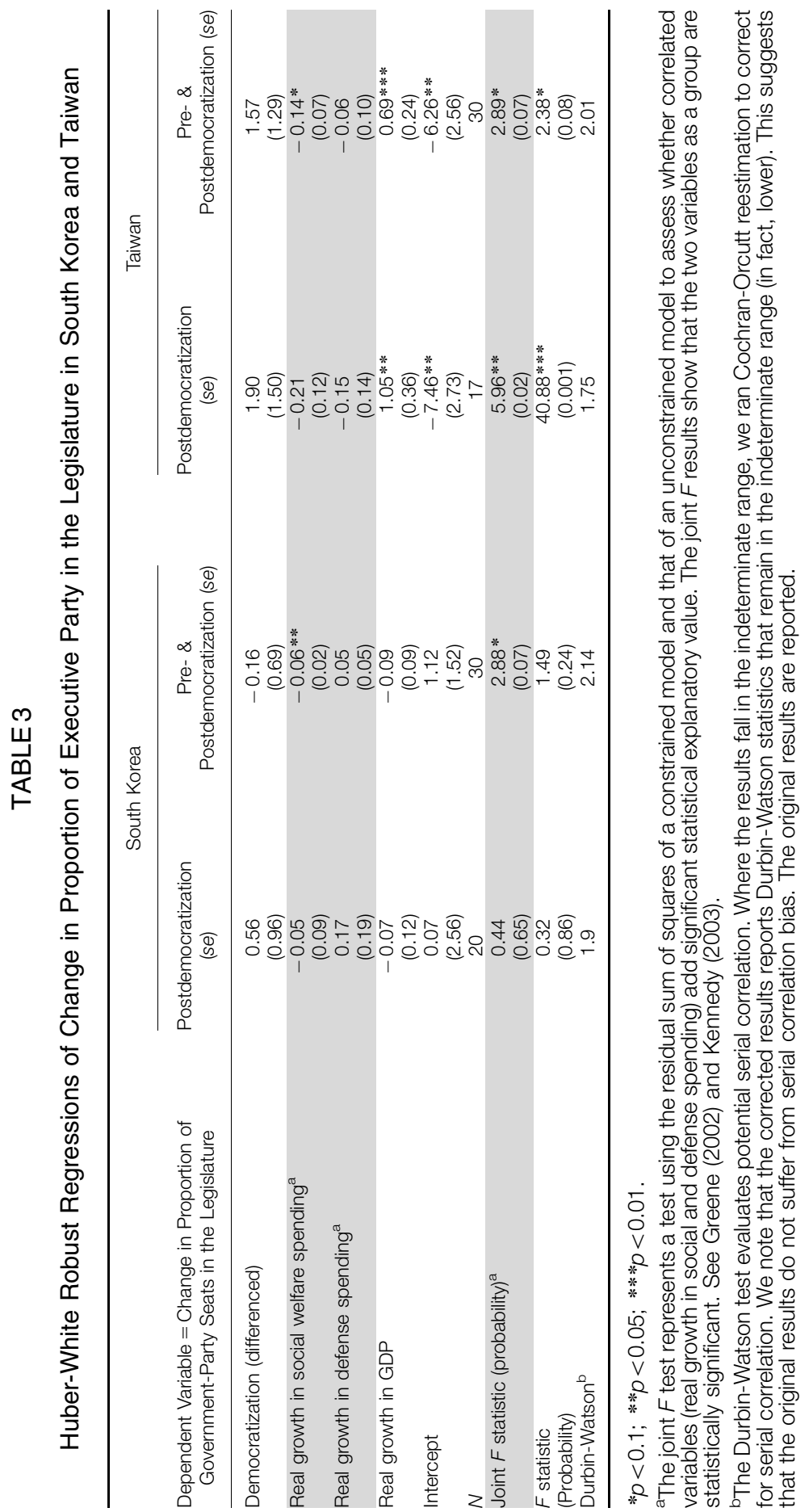


data series in both nations. A joint $f$ test shows that the two variables, social welfare allocations and defense spending, are statistically significant as a set in explaining the government margin (Greene, 2002; Kennedy, 2003). In essence, high correlation between the two variables inflated their standard errors to understate their statistical significance. This is corroborated by tests evaluating the variables individually. By these results, real growth in defense allocation increases the size of the government's party in the legislature in South Korea, while growth in social welfare allocations decreases it. For Taiwan, we also evaluate the social welfare allocations and defense spending jointly and the results show that they are statistically significant as a set. In the case of Taiwan, increases in both civilian and welfare allocations decrease the size of the government-party in the legislature. Table 4 tabulates the descriptive statistics of the variables used in the analyses for future replication.

Thus, the results not only point out that institutions matter in spending decisions but also how: it is interesting that presidential elections affect spending in Taiwan, while legislative elections matter for South Korea. The most-similar-systems approach rules out the commonalities between Taiwan and South Korea-such as their common semi-presidential systems and budgetary processes that accord the executive preeminence in spending decisions - as explanations. Instead, it is their divergence in institutional arrangements that likely explain spending. By this approach, institutional arrangements such as electoral term limits (South Korea has term limits on the presidency but not Taiwan) rise to the top in explaining how spending is used strategically. By this finding, studies on spending would benefit from including considerations of institutional arrangements.

Just as the results speak to the need to "disaggregate" institutions, they also echo the need to disaggregate policies to study their effects. Consider, for instance, the results for social spending on government-party in the legislature: Why would increases in civilian spending decrease the proportion of government-party seats? We suspect that the results speak to the need to understand how spending relates to specific changes in social policies. In particular, recent literature notes that political coalitions have different preferences over specific outcomes; these differences are often masked when social spending is not differentiated (Mares and Carnes, 2009; Mares, 2007). Thus, for instance, if the rise in social welfare spending captures growing entitlements from the expansion of benefits of previous periods rather than new government spending initiatives, these increases would likely not predict better electoral performance for the government (Haggard and Kaufman, 2008).

To summarize, the results largely support our expectations regarding spending patterns in South Korea and Taiwan. In particular, the results show that elections matter: in South Korea, legislative elections affect spending; in Taiwan, it is presidential elections. In both nations, elections lead to increases in defense spending but not in civilian allocations. The 


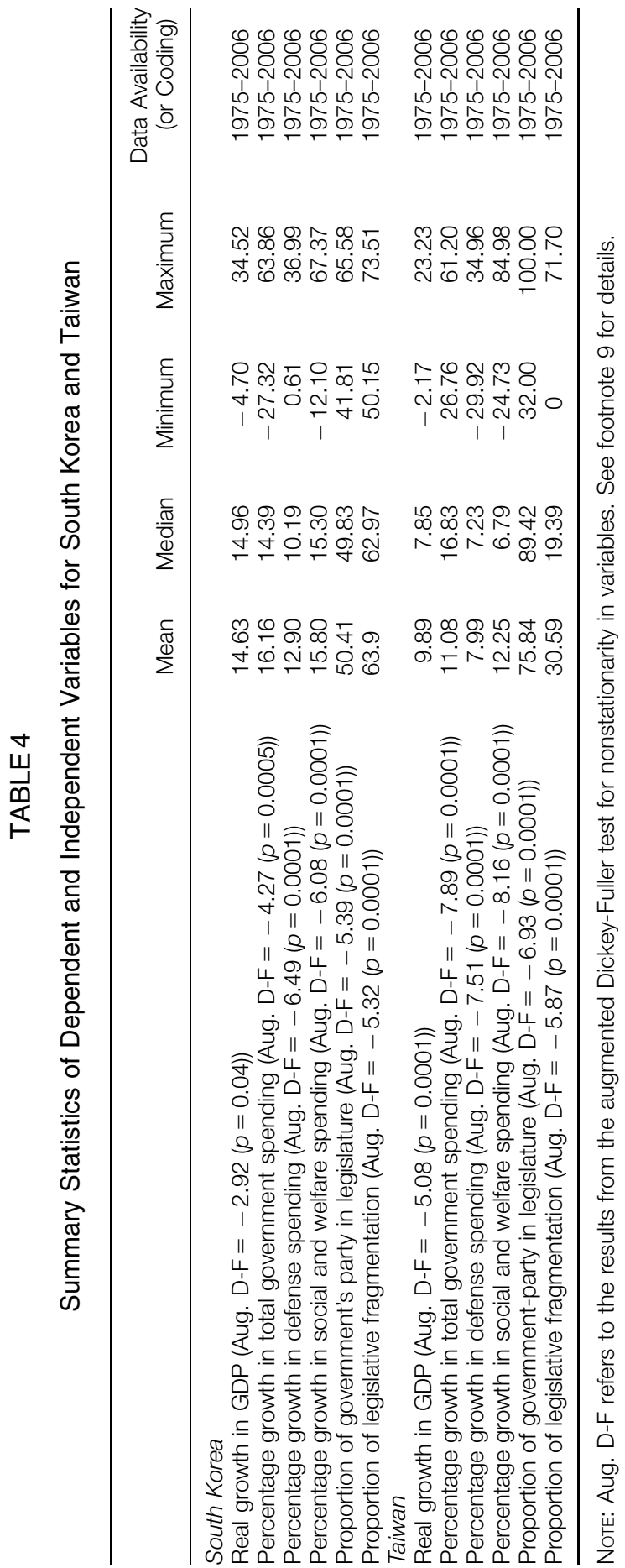


results from government spending on size of the government's party in the legislature are instructive: they show that government spending provides a viable alternative to building government support or party development. However, while real growth in defense spending increases the size of the government margin in the legislature in South Korea, in Taiwan, growth in defense spending decreases the size of the government-party in the legislature. These findings reiterate the need for new parties to build on their and the nation's strengths rather than focus on political divisiveness. The results also show that democratization does not affect spending patterns: when strategic spending is taken into account, the spending patterns are not structurally different in pre- and postdemocratization periods in the two nations. In part, the effect of democratization is indirect, that is, it is attenuated by the inclusion of variables such as size of the government-party, legislative fragmentation, and separate legislative and presidential elections. Thus, the results underscore that democratization may operate through these variables rather than directly. This highlights the relevance of democratization for changing spending priorities due its effect on increasing competitiveness. From this perspective, democratization lends emphasis to the relevance of government spending for party building under competitive conditions.

\section{Discussion}

South Korea and Taiwan are useful for study in part because of their democratic transitions from military-supported or one-party-dominated political systems. Further, the two nations share similarities in socioeconomic, political, and cultural characteristics that highlight the varied considerations that influence government spending and its divergent effects on political outcomes. Given their success, what lessons may be drawn regarding how government spending may be strategically used that does not undermine democratization?

The findings are instructive. First, they reveal electoral effects: in South Korea, legislative election years see changes in spending; in Taiwan, it is presidential election years. These nuances reflect strategic responses to the electoral settings of the respective nations. They also highlight the potential for resource competition between the different branches of the government that may undermine efforts to broaden or deepen electoral support to the detriment of democratization.

Second, in both nations, election years lead to growth in defense spending but not in civilian outlays. However, in South Korea, defense increases benefit the government's party by increasing its size in the legislature, while in the case of Taiwan, such defense increases are to the detriment of the government-party in the legislature. In the context of political developments in both nations, the results reiterate the need for parties to build on their and 
the nation's strengths rather than focus on political divisiveness to further democratization.

Third, democratization has no direct impact on spending. In particular, when the different strategic considerations that influence government spending are taken into account, spending patterns do not structurally diverge from pre- to postdemocratization periods in the two nations. Rather, the effect of democratization is attenuated by the inclusion of variables such as size of the government-party, legislative fragmentation, and separate legislative and presidential elections. Thus, the results underscore that democratization operates through these variables rather than by exerting a direct effect. This highlights the relevance of democratization for changing spending priorities due its effect on increasing competitiveness. The finding joins a growing literature to note that the effects of democratization on government spending are nuanced, so that it is useful to situate strategic considerations (such as "buying" constituency support) in government spending studies for pre and postdemocratization periods. Nevertheless, democratization is useful for showing how government spending is a viable resource for party building in competitive elections when it is targeted at building the nation's or party's strengths.

Equally important, the results underscore the need to contextualize government spending within the domestic context to clarify how it is strategically used. Without the context, the results for government spending in South Korea and Taiwan appear inconsistent with the literature. In their proper context, the results reveal that spending decisions in South Korea and Taiwan are similar across democratizing nations: they represent part of the effort to broaden electoral support or increase legislative backing or some combination of both without undermining democratization.

\section{REFERENCES}

Armstrong, Charles. 2001. “America's Korea, Korea’s Vietnam.” Critical Asian Studies 33(7):527-39.

Asian Development Bank. 1990-2008. Key Indictors of Developing Asian and Pacific Economies. Manila, Philippines: Asian Development Bank.

BBC Worldwide Monitoring. Various issues. Reading, UK: BBC Worldwide Monitoring.

Beck, Thorsten, George Clarke, Alberto Groff, Philip Keefer, and Patrick Walsh. 2001. "New Tools in Comparative Political Economy: The Database of Political Institutions." World Bank Economic Review 15(1):165-76.

Berman, Sheri. 2007. "Lessons from Europe.” Journal of Democracy 18(1):28-41.

Bollen, Kenneth, and Robert Jackman. 1989. "Democracy, Stability and Dichotomies." American Sociological Review 54(4):612-21.

Brown, David, and Wendy Hunter. 1999. "Democracy and Social Spending in Latin America, 1980-92." American Political Science Review 93(4):779-90. 
Carothers, Thomas. 2007. "The 'Sequencing' Fallacy." Journal of Democracy 18(1): $12-27$.

Chan, Steve. 1995. "Grasping the Peace Dividend: Some Propositions on the Conversion of Swords into Plowshares." Mershon International Studies Review 39(1):53-95.

Cheng, Tun-jen, and Stephan Haggard. 2001. "Democracy and Deficits in Taiwan: The Politics of Fiscal Policy." In Stephan Haggard and Mathew McCubbins, eds., Presidents, Parliaments, and Policy. New York: Cambridge University Press.

Central News Agency. Various issues. Taipei, Taiwan: Central News Agency.

Constitution of the Republic of China. Taipei, Taiwan. Available at $\langle$ http://www.presid ent.gov.tw/index_e.htm $\rangle$.

Constitution of the Republic of Korea. Seoul, Republic of Korea. Available at 〈http:// english.ccourt.go.kr $\rangle$.

Coppedge, Michael. 2002. "Democracy and Dimensions: Comments on Munck and Verkuilen." Comparative Political Studies 35(1):35-39.

Feng, Yi, Margaret Huckeba, Son Nguyen, and Aaron Williams. 2000. "Political Institutions, Economic Growth, and Democratic Evolution: The Pacific Asian Scenario." In Bruce Bueno de Mesquita and Hilton Root, eds., Governing for Prosperity. New Haven, CT: Yale University Press.

Freedom House. 1972-2009. Freedom in the World. New York: Freedom House.

Ghosn, Faten, Glenn Palmer, and Stuart Bremer. 2004. "The MID3 Data Set, 1993-2001: Procedures, Coding Rules, and Description." Conflict Management and Peace Science 21: $133-54$.

Greene, William. 2002. Econometric Analysis, 5th ed. Upper Saddle River, NJ: Prentice Hall.

Haggard, Stephan, and Robert Kaufman. 2008. Democracy, Development, and the Welfare State: Latin America, East Asia, and Europe. Princeton, NJ: Princeton University Press.

Kaufman, Robert, and Alex Segura-Ubiergo. 2001. "Globalization, Domestic Politics, and Social Spending in Latin America: A Time-Series Cross-Section Analysis, 1973-97." World Politics 53(4):553-87.

Keesings Record of World Events. Various issues. Bradford, UK: University of Bradford.

Kennedy, Peter. 2003. A Guide to Econometrics, 5th ed. Cambridge: MIT Press.

Korea Annual. 1973-2006. Seoul: Yonhap News Agency.

Kwon, Hyeok Yong. 2005. "Targeting Public Spending in a New Democracy: Evidence from South Korea.” British Journal of Political Science 35(2):321-41.

Lebovic, James. 2001. "Spending Priorities and Democratic Rule in Latin America." Journal of Conflict Resolution 45(4):427-52.

Mares, Isabella. 2007. "The Great Divergence in Social Protection.” Presented at Comparative Political Seminar. Princeton, NJ: Princeton University.

Mares, Isabela, and Matthew E. Carnes. 2009. "Social Policy in Developing Countries." Annual Review of Political Science 12:93-113.

Ministry of National Defense. 1990-2004. White Papers. Seoul, Republic of Korea: Ministry of National Defense. 2006. Defense Policy. Available at $\langle$ http://www.mnd.go.kr/ $\rangle$. 
New York Times. Various issues. New York: New York Times.

Oh, John Kie-chang. 1999. Korea Politics: The Quest for Democratization and Economic Development. Ithaca, NY: Cornell University Press.

Orenstein, Mitchell. 2008. "Post-Communist Welfare States." Journal of Democracy 19(4):80-94.

Pereira, Carlos, Timothy J. Power, and Lucio Rennó. 2005. "Under What Conditions Presidents Resort to Decree Power? Theory and Evidence from the Brazilian Case." Journal of Politics 67(1):1978-2000.

Reich, Gary. 1999. "Coordinating Restraint: Democratization, Fiscal Policy and Money Creation in Latin America." Political Research Quarterly 52(4):729-51.

Republic of China Yearbook. 1981-1998. Taiwan: Government Information Office.

Samuels, David, and Fernando Luiz Albrucio. 2000. "Federalism and Democratic Transitions: The 'New' Politics of the Governors in Brazil." Publius 30(2):43-61.

Schedler, Andreas. 2002. “The Menu of Manipulation.” Journal of Democracy 13(2):36-50.

Stasavage, David. 2005. "Democracy and Education Spending in Africa." American Journal of Political Science 49(2):343-58.

Taipei Times. Various issues. Taipei, Taiwan: Taipei Times.

Taiwan Communique. Various issues. Washington, DC: International Committee for Human Rights in Taiwan.

Tien, Hung-mao. 1996. "Taiwan in 1995: Electoral Politics and Cross-Strait Relations." Asian Survey 36(1):33-40.

Treisman, Daniel, and Vladimir Gimpelson. 2001. "Political Business Cycles and Russian Elections." British Journal of Political Science 31(2):225-46.

Yap, O. Fiona. 2005. Citizen Power, Politics and the "Asian Miracle": Assessing the Dynamics. Boulder, CO: Lynne Rienner Publisher.

Yonhap News Agency. Various issues. Seoul, Republic of Korea: Yonhap News Agency. 